\title{
Corticotropin-Releasing Factor Receptor 1
}

National Cancer Institute

\section{Source}

National Cancer Institute. Corticotropin-Releasing Factor Receptor 1. NCI Thesaurus. Code C75664.

Corticotropin-releasing factor receptor 1 (444 aa, $51 \mathrm{kDa}$ ) is encoded by the human CRHR1 gene. This protein is involved in the stimulation of corticotropin release. 